УДК 37.01(036)

(C) Золотухіна С.Т., Іонова О.М., Лупаренко С.С., 2019 р.

http://orcid.org/0000-0002-3535-5974

http://orcid.org/0000-0002-9306-5553

http://orcid.org/0000-0002-3111-5340

DOI: $10.34142 / 23128046.2019 .47 .04$

C. T. Золотухіна

О. М. Іонова

С. Є. Лупаренко

\title{
МУЗИЧНА ОСВІТА ШКОЛЯРІВ У ЗАКЛАДАХ ЗАГАЛЬНОЇ СЕРЕДНЬОЇ ОСВІТИ КНР: ТЕНДЕНЦІЇ ТА ПЕРСПЕКТИВИ
}

Актуальність дослідження зумовлена недостатньою розробкою в педагогічі проблеми музичної освіти школярів у закладах загальної середньої освіти КНР, значущістю використання педагогічно иінного китайського досвіду музичної освіти у вітчизняній освітній практиці. Метою дослідження є висвітлення тенденцій і перспектив музичної освіти школярів у закладах загальної середньої освіти КНР.

Використано загальнонаукові (аналіз, синтез, систематизація, узагальнення, порівняння, класифікація), історичні, емпіричні, прогностичні методи дослідження. Розкрито загальні тендениії розвитку музичної освіти в закладах загальної середньої освіти КНР в історичному, змістовому, організаційно-методичному аспектах. Визначено спільні тендениії розвитку музичної освіти в закладах загальної середньої освіти Украйни та КНР: прогресивність загальної стратегії музичної освіти, ї̈ спрямованість на розвиток духовності начії; демократизаџія освітнього прочесу; відкритість світовому й європейському досвіду; постійна модернізація змісту освіти, форм і методів його засвоєння; поліпшення умов освітнього процесу; збільшення уваги до професійної підготовки вчителів музики.

Перспективними напрямами розвитку музичної освіти школярів у закладах загальної середньої освіти КНР $\epsilon$ : інтенсифікація наукових досліджень та активізачія впровадження інновачій у практику музичной освіти; створення начіональної концепиії загальної музичної освіти 3 урахуванням прогресивного світового досвіду та національних культурних традииіи; розроблення навчальних програм загальної середньої музичної освіти з урахуванням специфріки і можливостей регіонів, поєднання традииій та інновачій у музичній педагогічі. Визначено напрями використання китайського досвіду в сучасній школі Украйни: розробка концепџій музичной освіти школярів з урахуванням реалій $і$ перспектив розвитку вітчизняної освіти, національних і загальнолюдських культурних традичій; засвоєння зростаючим поколінням найважливіших иінностей засобами музичного мистечтва; забезпечення педагогічно доцільної організації та поліпшення 
умов здійснення музичної освіти школярів; підвищення вимог до професійності вчителів музики.

Ключові слова: музична освіта, школярі, заклади загальної середньої освіти, КНР, тендениії, перспективи.

Zolotukhina S. T., Ionova O. M., Luparenko S. Ye. Music Education of Schoolchildren in General Secondary Education Institutions in the People's Republic of China: Tendencies and Prospects. The relevance of the study is predetermined by insufficient development of the problem of schoolchildren's music education in general secondary education institutions in the People's Republic of China and the significance of the use of educationally valuable Chinese experience in music education in Ukrainian educational practice.

The aim of the study is to reveal the tendencies and prospects for schoolchildren's music education in general secondary education institutions in the People's Republic of China.

Various methods have been used to carry out this research, namely: general scientific (analysis, synthesis, systematization, generalization, comparison, classification), historical, empirical and prognostic methods.

The general tendencies of development of music education in general secondary education institutions in the People's Republic of China in historical, content and organizational-methodical aspects have been revealed. The general trends of development of music education in general secondary education institutions in Ukraine and the People's Republic of China have been determined. They are the progressiveness of the general strategy of music education, its focus on the development of spirituality of the nation, democratization of educational process, openness to the world and European experience, constant modernization of the content of education, forms and methods of mastering it, improvement of the conditions of educational process, increased attention to Music teachers' professional training.

The prospects for development of schoolchildren's music education in general secondary education institutions in the People's Republic of China have been specified. They are the intensification of scientific research and intensifying the implementation of innovations into the practice of music education, the creation of a national concept of general music education taking into consideration the progressive world experience and national cultural traditions, development of curricula of general secondary music education taking into account the specificity and opportunities in the region, the combination of tradition and innovation in music pedagogy.

The directions of the use of Chinese experience in modern schools in Ukraine have been determined. They are the development of a concept of schoolchildren's music education taking into account the realities and prospects for the development of national education, universal and national cultural traditions, children's assimilation of the most important values by means of musical art, providing pedagogically appropriate organization and improving the 
conditions of children's music education, increasing the requirements for Music teachers' professionalism.

Keywords: music education, schoolchildren, general secondary education institutions, the People's Republic of China, tendencies, prospects.

Вступ. Реалізація Концепції «Нова українська школа» спрямована на формування у школярів ключових компетентностей для життя. Однією 3 визначених компетентностей $\epsilon$ обізнаність та самовираження у сфері культури, що передбачає глибоке розуміння власної національної ідентичності як підгрунтя відкритого ставлення та поваги особистості до розмаїття культурного вираження інших людей (Zakon Ukrainy «Pro reformuvannia osvity» ta stvorennia «Novoi ukrainskoi shkoly», 2017). 3 огляду на це особливої актуальності набувають питання музичної освіти особистості для iї подальшого культурного життя.

Нагальна потреба пошуку нових підходів до вирішення проблеми музичної освіти школярів потребує вивчення шляхів розв'язання цієї проблеми в зарубіжній педагогіці. На особливу увагу заслуговує аналіз досвіду КНР - держави, яка серед країн світу за загальними соціальноекономічними показниками стає однією з провідних держав сучасності. Одним із чинників успішного розвитку цієї країни вважається пильна увага та значні інвестиції Уряду в освіту підростаючого покоління. Це закономірно призводить до результативності системи освіти КНР з огляду на якість викладання, затребуваності людини на ринку праці, забезпечення іiі наступного професійного зростання тощо.

Сучасна система освіти КНР знаходиться у стадії реформування. Основним трендом освітніх реформ, як і в багатьох європейських країнах, виступає гуманізація китайської освіти, iї спрямування на формування всебічно розвиненої творчої особистості, здатної швидко адаптуватися до умов життя, що постійно змінюються. У вирішенні означених завдань велика увага приділяється залученню мистецтва в освітній процес: на державному рівні утверджується особлива роль музичного мистецтва й музичної освіти в загальному розвитку дітей і молоді, створенні соціально-духовної нації.

Аналіз психолого-педагогічних джерел дає можливість зробити висновок про те, що музична освіта школярів у закладах загальної середньої освіти КНР знаходиться в полі уваги вчених, педагогів країни. Дослідниками розглядаються як історичні аспекти (Ван Юйхе, Сю Хайлінь, Цюй Баокуй та ін.), так і сучасний стан (Ван Юечжи, Су Цзюнь, Чжоу Шэннань, Ян Бохуа та ін.) музичної освіти школярів. Окремі аспекти музичної освіти учнів 
висвітлено в історико-педагогічних працях китайських науковців (Ван Цхіан, Джуанлін Х, Л. Ліу, Уюнтена,Фу К, Ху I, Чен Л) (Ionova \& Yiechzhy, 2019).

У вітчизняному освітньому просторі проблема музичної освіти школярів у закладах загальної середньої освіти досліджується в різних напрямах, зокрема: наукові основи педагогіки мистецтва та музичної педагогіки (О. Олексюк, О. Рудницька), теорія і методика музичної освіти (О. Ростовський), викладання мистецьких дисциплін (Г. Падалка), історія гуманізації музичної освіти (С. Горбенко), розвиток музичної освіти учнів (Т. Раструба) тощо (Horbenko, 2008).

Слід відзначити, що проблемі музичної освіти підростаючого покоління присвячена значна кількість публікацій видатних музикантів i музичних педагогів (Б. Барток, Е. Віла-Лобос, З. Кодай, І. Менухін, К. Орф, Д. Хворостовський та ін.), які наголошують на значущості музики як поводиря на шляху поточних та прийдешніх завдань людства (Viunsh, 1998; Ionova, 1997; Ionova \& Yiechzhy, 2019).

Світова освітня практика свідчить про те, що поглиблена музична освіта позитивно впливає на розвиток школярів: стимулює мотивацію до навчання i навчальних досягнень, сприяє розвитку креативності, концентрації уваги і зростанню коефіцієнта інтелекту (IQ), поліпшує емоційне самовідчуття, дисциплінує дітей, підвищує рівень шкільної успішності (незважаючи на збільшення навантаження), уможливлює оптимізацію взаємодії особистості й соціуму (Viunsh, 1998).

Важливу роль в осмисленні предмета, що вивчається, відіграли дослідження вітчизняними вченими (Ю Лахмотова, О. Михайліченко, Р. Роман, Л. Царьова, О. Шрестха) різних питань загальної середньої освіти в Китаї, зокрема музичної освіти вальдорфських школярів (О. Іонова) (Ionova \& Yiechzhy, 2019).

Проте вищезазначені праці не охоплюють усього спектру досліджуваної проблеми, зокрема залишаються недостатньо вивченими питання загальних тенденцій і перспектив розвитку музичної освіти учнів у школах КНР.

Мета та завдання. Мета дослідження - висвітлити тенденції та перспективи розвитку музичної освіти школярів у закладах загальної середньої освіти КНР. Завдання: з'ясувати тенденції та окреслити перспективи розвитку музичної освіти школярів у закладах загальної середньої освіти КНР; узагальнити спільні тенденції розвитку музичної освіти учнів у школах України та КНР; визначити напрями використання китайського досвіду в сучасній школі України. 
Методи дослідження. Використано такі методи дослідження: загальнонаукові (аналіз, синтез, систематизація, узагальнення, порівняння, класифікація наукових джерел), що стало основою для з'ясування ступеня наукової розробки проблеми, висвітлення думок китайських науковців, педагогів щодо порушеної проблеми, узагальнення тенденцій розвитку музичної освіти школярів у закладах загальної середньої освіти КНР; історичні, які дали змогу висвітлити проблему дослідження в динаміці й у хронологічній послідовності; емпіричні (ретроспективний, діагностичний, праксиметричний), що сприяли розкриттю особливостей змісту, форм, методів музичної освіти школярів у школах КНР; порівняльно-зіставні, які дозволили порівняти тенденції розвитку музичної освіти школярів у школах України та КНР; прогностичні, що забезпечили критичне оцінювання та окреслення перспектив розвитку музичної освіти школярів у закладах загальної середньої освіти КНР.

Результати. Проведений науковий пошук свідчить, що в Китаї виховна спрямованість музичної освіти існувала одвічно, оскільки музика 3 давніх часів розумілася китайцями в тісному зв'язку з моральними устоями світобудови. Стародавні китайські філософи, зокрема Сюнь-Цзи (315-236 pp. до н.е.), вбачали в музиці основу гармонії як ідеального устрою світу. Невипадково в китайській пентатоніці кожний звук ладу відповідає основним явищам і станам природи: перший ступінь - центр, земля, жовтий, вітер; другий ступінь - захід, метал, білий, холод; третій ступінь - схід, дерево, зелений, спека; четвертий ступінь - південь, вогонь, червоний, світло; п'ятий ступінь - північ, вода, чорний, дощ (Su. Tsziun, n. d.).

Звідси випливає висновок про те, що музика здатна встановити гармонію людини та природи, особистості й суспільства. Це визначає загальну ціннісну спрямованість шкільної музичної освіти, іiї значення в розвитку доброчесності в новому поколінні, зміцненні духовності нації. Ціннісно-цільові орієнтири загальної музичної освіти школярів у Китаї визначають вектор іiі розвитку, специфіку та функції, сприяють або перешкоджають реалізації місії музичного мистецтва в розвитку людського потенціалу.

Змінювання цілей загальної музичної освіти школярів за часів існування КНР як незалежної держави (із 1949 р. по цей час) відбувалося поступово і пройшло декілька етапів, а саме: етап стабілізації (1949-1965 pp.), який характеризується стандартизацією цілей музичної освіти школярів (естетичне виховання засобами співу), що було наслідком упроваджування радянської системи освіти загалом і радянської моделі музичної освіти зокрема; етап регресу (1966-1976рр.), що за часом збігається з Великою 
культурною революцією та відзначається спрощенням цілей музичної освіти, в основі яких були цінності політичної ідеології (ідейність, поклоніння культу особистості Мао, непримиримість до класових ворогів); етап реконструювання (1977-1988рр.), який позначився входженням КНР у нову фазу розвитку соціалізму і відтворенням майже зруйнованої системи освіти та характеризується поступовим переосмисленням цінностей і цілей музичної освіти, поверненням ій поліфункціонального характеру; етап концептуалізації (із 1989 р. по цей час), що відмічений соціальним замовленням на розвиток якісних характеристик нації, характеризується підвищенням статусу й місії музичної освіти, поширенням іiі на всі вікові категорії школярів, уточненням цілей із урахуванням інтересів особистості, суспільства й держави.

Відзначимо, що на етапі концептуалізації, із переходом національної системи освіти від моделі «школа задля вищого навчального закладу» до моделі «поліпшення якісних характеристик нації», соціальна значущість музичної освіти значно збільшилася, спостерігається прагнення до найбільш повної реалізації потенціалу музичної освіти в розвитку людини та суспільства. Цінність музичної освіти почала розглядатися 3 позицій антропологічного підходу. У формуванні цілей музичної освіти, окрім держави (виховання громадян і патріотів своєї країни, яким притаманна висока духовна культура та розвинений творчий потенціал) та суспільства (формування базової художньо-естетичної й музичної культури), усе більше починають брати участь самі школярі як суб'єкти освітнього процесу (розвиток потреб і здібностей у художньо-творчому самовираженні засобами різних видів музичної діяльності).

Основними виховними завданнями сучасної музичної освіти китайських школярів $\epsilon$ : виховання любові до своєї країни, народу; удосконалення естетичних почуттів школярів; виховання в учнів інтересу до музики, розвиток навичок гри та співу, читання нот; виховання в учнів національної гордості на прикладах китайського фольклору, а також розширення музичного досвіду шляхом знайомства з іноземними творами.

Як зазначено вище, одним із найважливіших завдань є виховання патріотизму на основі формування визначених рис характеру. Загальна музична освіта базується на патріотичній ідеї та народних традиціях. Цілком справедливим вважається те, що мова музики для дітей є початком розуміння національних особливостей країни, вияву любові до держави та її музичної культури. Музика надихає дітей слідувати ідеалам, формує стійкий характер, оптимізм, розвиває здатність проникати в суть думок і почуттів. 
Конкретизація цілей і завдань музичної освіти здійснюється на рівні іiі змісту, спрямованого на засвоєння школярами певних знань, умінь, досвіду, розвитку здібностей, формування духовних цінностей засобами музичного мистецтва. Зміст музичної освіти відбивається, насамперед, у навчальнометодичному забезпеченні уроків музики, тобто в навчальних програмах, підручниках, навчальних посібниках.

Здійснений Чжоу Шеннанем аналіз історичної динаміки змісту музичної освіти школярів у КНР засвідчив, що у змістовому аспекті спостерігається набуття незалежного статусу музичного виховання в ідейних концептах; зміна пріоритетів, які визначають логіку побудови змісту навчального матеріалу (на зміну ланцюжка «співи - основи музичних знань, умінь і навичок - музичне виховання» приходить послідовність «музичне виховання - музична діяльність - музичні знання й уміння»); відмова від соціально-політичної детермінанти у відборі музичного репертуару на користь культуровідповідного й особистісно значимого змісту навчального матеріалу; перехід від спрощеного й одноманітного (уроки співу) до складного й різноманітного (уроки музики) змісту навчальних посібників; удосконалення оформлення навчальної літератури (з огляду на іï естетичну привабливість) (Zhou Shengnan, 2018).

Згідно зі «Стандартами навчального курсу музики в межах обов'язкової освіти» (2011р.) зміст музичної освіти втілюється в таких основних аспектах: відчуття та сприйняття; виконання (виступ); творчість і створювання; взаємозв'язок музики та соціуму (Sait Ministerstva osvity KNR, n. d.). Отже, концептуальною ідеєю $\epsilon$ «виховання людини красою». Розроблені відповідно до означених «Стандартів» підручники містять підбір найкращих музичних творів (різноманітних як за жанром, так і за формою виконання), наявність великої кількості творчих завдань тощо.

Слід наголосити на тому, що зміст музичної освіти школярів у КНР за останні десятиліття увібрав у себе найкращі європейські підходи, проте суттєво модернізований і адаптований як до сучасного етапу розвитку, так $\mathrm{i}$ можливостей якісного викладання саме в китайських школах.

За останній час інтеграційні процеси та відкритість європейському досвіду набули найбільш явного характеру. Вивчення й адаптація європейського досвіду здійснюється через дружні зв'язки з іншими країнами, запрошення фахівців-музикантів - як педагогів (зокрема з України), так i музикантів-виконавців; в активному будівництві концертних залів, виїздах китайської молоді з метою навчання за кордоном тощо.

Просування до мети різнобічного розвитку особистості простежується й у застосуванні домінуючих методів, засобів, технологій музичної освіти. В 
організаційно-методичному аспекті відбувається збільшення кількості годин, що відводиться на музичні заняття, поширення їх на всі ступені загальної середньої освіти. Так, у сучасній школі КНР уроки музики у 1-4-х класах проводяться двічі на тиждень, із п'ятого класу - один урок на тиждень. Курс початкової музичної освіти, який відбувається як на уроках музики, так і на заняттях під час канікул, містить співи пісень, слухання музики, гру на музичних інструментах, а також музичні ігри, закріплення музичних знань. Водночас провідним методом роботи є співи пісень, оскільки вони сприяють передачі мистецтва співу, без якого людина не може виявити й виразити себе.

Значна увага у процесі навчання приділяється національній китайській музиці. Спеціальне вивчення китайської пісні починається з другого класу, коли учні вже підготовлені до різних форм роботи. Особливе місце у шкільній програмі посідає блок, присвячений китайській опері (у 2001 році китайська традиційна опера Куньцюй була включена ЮНЕСКО у перелік шедеврів усної й нематеріальної спадщини людства).

Національна система музичної освіти збагачується прогресивними зарубіжними методиками музичного виховання. Провідні системи музичного виховання (Є. Жак-Далькроз, Д. Кабалевський, 3. Кодай, К. Орф), відома в європейських країнах система цифрових нот та багато іншого знайшли своє відбиття в китайському практичному досвіді викладання 3 опорою на усталені народні традиції.

Зазвичай у класі навчається від 25 до 40 учнів, із них до 10 осіб вчаться грі на музичних інструментах на платній основі (це може бути організовано при університетах або в домашніх умовах - як репетиторство). Одним із найпопулярніших інструментів $є$ фортепіано; користуються популярністю також скрипка, флейта, саксофон, ударні інструменти.

Стимулюючим чинником засвоєння гри на інструменті, виступає народна традиція чіткого розмежування майстерності на певні рівні (9 рівнів, як у спорті) із ретельно розробленим методичним комплексом. Засвоєння кожного рівня контролюється спеціальними комісіями з атестації. I тут варто відзначити тенденцію об'єднання професійної й загальної музичної освіти, оскільки інтенсивний розвиток інструментального заняття музикою створює художньо розвинене середовище й унікальні можливості для духовного розвитку підростаючого покоління засобами мистецтва. У кожній школі працює два або три викладачі музики. Учителі музики грають на фортепіано й на іншому музичному інструменті за вибором. Як правило, це національний китайський інструмент (флейта, арху, пипа тощо), за допомогою якого вчитель виконує нескладну музику й акомпанує співам. 
У кожній школі, окрім уроків музики, є хоровий колектив (заняття двічі на тиждень), який готує концертні програми й бере участь у конкурсах. Хорові конкурси проводяться щорічно. За бажанням учителя замість хору в школі може бути оркестр або танцювальний ансамбль.

У сучасній музичній освіті школярів спостерігається розширення практичних видів музичної діяльності, зміщення акцентів із репродуктивних на репродуктивно-творчі та творчі методи. Так, набувають популярності такі методи: дослідження звуків і музики (удавати природні та життєві звуки людським голосом або на ударних інструментах); спонтанна музична діяльність (задоволення потреби у творчому самовираженні дітей молодшого шкільного віку за власної ініціативи у спеціально створених умовах для індивідуальної або групової музичної діяльності); імпровізація (виконання дитячих і народних пісень у різних ритмах, із різною швидкістю й інтенсивністю, супровід музичних звуків адекватними тілесними рухами, супровід музичних оповідань та ігор нескладними імпровізаціями на камерних, народних, шумових інструментах тощо); творча практика (відбиття почутої музики лініями, кольоровими відтінками, малюнками, рухами; створення 2-3 тактів ритмічного рисунка для виконання голосом, музичним або шумовим інструментом); синтезування близьких видів мистецтва (використання багатозначних, промовистих, образних засобів суміжних видів мистецтва для відображення й інтерпретації музичних творів); творча музична діяльність як соціальна практика (розуміння ролі музики в житті, бажана участь у музичній діяльності, отримання насолоди від музики завдяки засобам масової інформації, участь у музичні діяльності у спільнотах та в селах тощо) (Zhou Shengnan, 2018).

В організації музичної освіти школярів постійно розширюється коло різноманітних форм позакласної музичної діяльності, завдяки чому вона набуває колективного характеру; підвищуються вимоги до комплектування музичних кабінетів i класів необхідними інструментами, технікою, обладнанням; відбувається активний розвиток інформаційно-комунікативних технологій для організації та стимулювання різних видів музичної діяльності.

Із початком XXI століття суттєво змінилося обладнання класів шкіл, зокрема й кабінетів музики. Учительський стіл повністю обладнаний необхідною для роботи технікою: комп'ютер із монітором і проектором на екран, DVD-програвач, музичний центр і пристрій для обробки звука. У кабінеті музики є фортепіано та інші музичні інструменти. Учитель зазвичай робить нескладний наочний супровід уроку в комп'ютерній програмі POWER POINT. Навчально-методичний комплекс із музики включає мультимедійне забезпечення теми уроку, яскраво оформлені підручники, 
аудіозаписи акомпанементу пісень, які відтворюються на DVD-програвачі. Усе це сприяє популяризації музичного мистецтва, «моді» на музичне виконавство серед молоді, що $є$ одним із найважливіших чинників розвитку духовної культури нації.

Поряд із позитивними тенденціями розвитку музичної освіти школярів у закладах загальної середньої освіти КНР виявлено й певні негативні тенденції, серед яких, насамперед: суперечність між рівнем розвитку науки та впровадженням інновацій у практику музичної освіти; нерівномірність реформування музичної освіти школярів по країні, залежність іï від рівня економічного розвитку регіону (Yan, 2008).

Обговорення. З'ясування загальних тенденцій розвитку музичної освіти в закладах загальної середньої освіти КНР (в історичному, змістовому та організаційно-методичному аспектах), а також вивчення вітчизняних наукових джерел із музичної освіти школярів (Horbenko, 2008; Oleksiuk, 2006; Padalka, 2008; Rastruba, 2015; Rostovskyi, 2011; Rudnytska, 2002) дозволяє порівняти тенденції розвитку музичної освіти школярів у школах України та КНР і визначити спільні серед них. Такими спільними тенденціями $\epsilon$ : прогресивність загальної стратегії музичної освіти, іiі спрямованість на розвиток духовності нації, формування досвіду емоційноціннісного ставлення до дійсності, музичних знань, музичних умінь і навичок творчої самореалізації в різних видах музичної діяльності школярів; демократизація освітнього процесу (можливість вибору школярем освітньої концепції й авторської програми 3 музики); відкритість світовому й європейському досвіду; постійна модернізація змісту освіти, форм і методів його засвоєння; поліпшення навчально-методичного та матеріального забезпечення освітнього процесу; збільшення уваги до професійної підготовки та перепідготовки педагогічних кадрів - учителів музики.

Висновки. Здійснений науковий пошук свідчить про те, що загальною історичною тенденцією розвитку музичної освіти школярів у закладах загальної середньої освіти КНР є рух від запозичення цінностей і цілей у радянській системі (50-ті pp. ХХ століття) до усвідомленого й концептуально обгрунтованого цілепокладання в сучасній системі музичної освіти, яка постійно розвивається. У змістовому аспекті тенденцією розвитку музичної освіти школярів $\epsilon$ набуття незалежного від ідейно-політичного статусу музичного виховання в ідейних концептах і перехід від спрощеного й одноманітного (уроки співу) до складного й різноманітного (уроки музики) змісту навчальних посібників. В організаційно-методичному аспекті основною тенденцією розвитку музичної освіти школярів є збільшення кількості годин уроків музики, поширення їх на всі рівні загальної середньої 
освіти, розширення практичних видів музичної діяльності, зміщення акцентів iз репродуктивних на репродуктивно-творчі та творчі методи.

Перспективними напрямами розвитку музичної освіти школярів у закладах загальної середньої освіти КНР $є$ такі: інтенсифікація наукових досліджень у галузі музичної освіти та активізація впровадження інновацій у сучасну практику музичної освіти; створення національної концепції загальної музичної освіти з урахуванням прогресивного світового досвіду та національних культурних традицій; розроблення навчальних програм для всіх рівнів загальної середньої освіти 3 урахуванням специфіки i можливостей регіонів, поєднання традицій та інновацій у музичній педагогіці; узгодження програм підготовки вчителів музики 3 програмами загальної середньої освіти.

3 урахуванням як позитивних, так і негативних тенденцій розвитку музичної освіти школярів у закладах загальної середньої освіти КНР визначено напрями використання китайського досвіду в сучасній школі України, а саме: розробка концепцій музичної освіти школярів з урахуванням реалій i перспектив розвитку вітчизняної освіти, національних i загальнолюдських культурних традицій; засвоєння зростаючим поколінням найважливіших цінностей як основи створення соціально-духовної нації; забезпечення педагогічно доцільної організації музичної освіти школярів, використання різноманітних форм та методів, спрямованих на диференціацію й індивідуалізацію музичної освіти, активізацію навчально-пізнавальної діяльності школярів; поліпшення умов (матеріальне й навчально-методичне забезпечення, створення й оснащення кабінетів музики сучасною технікою, комп'ютерами, доступом до Інтернет ресурсів тощо) здійснення музичної освіти школярів; підвищення вимог до вчителів музики, посилення заходів, що заохочують їх до постійного самовдосконалення.

\section{ЛІТЕРАТУРА:}

Вюнш В. Формирование человека посредством музыки: [пер. с нем. Н.Т.Григорьевой]. Москва: Парсифаль, 1998. 160 с.

Горбенко С. Історія гуманізації музичної освіти дітей шкільного віку : навч. посіб. Житомир : В. Б. Котвицький, 2008. 416 с.

Ионова Е.Н. Вальдорфская педагогика: теоретико-методологические аспекты: [монография]. Харьков: Бизнес-Информ, 1997. 300 с.

Ионова Елена, 王越之《音乐教育和教育华德福教音法》北方音乐,

音教论坛, 中国, 2019, № 11， 103-105页。(Олена Іонова, Ван Юечжи. Музичне виховання та навчання у початковій Вальдорфській школі. Північна музика, практичний форум, Китай. 2019. № 11. С. 103 - 105).

Олексюк О. Музична педагогіка : навч. посіб. Київ : КНУКіМ, 2006. 188 с.

Падалка Г. Педагогіка мистецтва (теорія і методика викладання мистецьких дисциплін). Київ : Освіта України, 2008. 274 с. 
Раструба Т. Розвиток музичної освіти учнів загальноосвітніх навчальних закладів України XXI століття: особистісно-орієнтований підхід. Актуальні питання гуманітарних наук: зб. наук. праць молодих вчених Дрогобицького державного педагогічного університету імені Івана Франка, 2015. Вип. 13. С.145-152.

Ростовський О. Теорія і методика музичної освіти : навч.-метод. посіб. Тернопіль : Навчальна книга - Богдан, 2011. 640 с.

Рудницька О. Педагогіка: загальна та мистецька: навч. посіб. Київ : Освіта, 2002. 270 с.

Сайт Міністерства освіти КНР. Режим доступу: http://www.moe.gov.cn (дата звернення: 02.12.2019)

Су Цзюнь. Тенденции современного музыкального образования детей в России и Китае (в аспекте сравнительно педагогики). Режим доступу: http://www.jurnal.org/articles/2013/ped54.html (дата звернення: 30.11.2019)

Чжоу Шэннань. Развитие общего музыкального образования в Китае (1950-2014 гг.) : автореф. дис. ...канд. пед. наук: 13.00.01. Минск, 2018. 20 с.

Ян Бохуа. Музыкальное воспитание в общеобразовательной школе современного Китая : дис. ...канд. педаг. наук : 13.00 .02 / РГПУ им. А. И. Герцена. Санкт-Петербург, 2008. $161 \mathrm{c}$.

Ionova E.N., Lakhmotova Y.V. Question of learning English in the Waldorf schools of China. Virtus, 2017. Iss. 17 (October). P. 109-111.

\section{REFERENCES:}

Vjunsh, V. (1998). Formirovanie cheloveka posredstvom muzyki [The formation of a man through music] (Trans. from German). Moscow: Parsifal (in Russian).

Horbenko, S. (2008). Istoriia humanizatsii muzychnoi osvity ditei shkilnoho viky [History of humanization of schoolchildren's music education]. Zhytomyr : V. B. Kotvytskyi (in Ukrainian).

Ionova, E. (1997). Val'dorfskaja pedagogika: teoretiko-metodologicheskie aspekty. [Waldorf Pedagogy: theoretical-methodical aspects]. Kharkov: Business-Inform (in Russian).

Ionova, Ye. \& Yiechzhy, V. (2019). Muzychne vyhovannia ta navchannia u pochatkoviy valdorfskiy shkoli [Music education in primary Waldorf school]. Pivnichna muzyka, practychnyi forum, Kutai (Northern music, practical forum, China), 11, 103-105 (in Chinese).

Oleksiuk, O. (2006). Muzychna pedagogika [Musical pedagogy]. Kyiv: KNUKiM (in Ukrainian).

Padalka, H. (2008). Pedagogika mystetstva (teoriia $i$ metodyka vykladannia mystetskykh dystsyplin) [Pedagogy of art (theory and methodics of teaching art disciplines)]. Kyiv : Osvita Ukrainy (in Ukrainian).

Rastruba, T. (2015). Rozvytok muzychnoi osvity uchniv zahalnoosvitnikh navchalnykh zakladiv Ukrainy XXI stolittia: osobystisno-orientovannyi pidkhid [The students' music education development of secondary educational institutions in Ukraine of the $21^{\text {st }}$ century: personoriented approach]. Actualni pytannia humanitarrnykh nauk (Humanities Science Current Issues), 13, 145-152 (in Ukrainian).

Rostovskyi, O. (2011). Teoriia i metodyka muzychoi osvity [Theory and methodics of music education]. Ternopil : Navchalna knyha - Bohdan (in Ukrainian).

Rudnytska, O. (2002). Pedahohika: zahalna ta mystetska [Pedagogy: general and art]. Kyiv : Osvita (in Ukrainian).

Sait Ministerstva osvity KNR [Site of Ministry of education of the People's Republic of China]. Retrived from http://www.moe.gov.cn (in Chinese).

Su, Czjun' (n. d.). Tendencii sovremennogo muzykal'nogo obrazovanija detej v Rossii $i$ Kitae (v aspekte sravnitel'noj pedagogiki). [Tendencies of children's modern music education in Russia and China (in the aspect of comparative pedagogy)]. Retrived from http://www.jurnal.org/articles/2013/ped54.html 
Zhou, Shengnan. (2018). Razvitie obshchego muzykalnogo obrazovaniya v Kitae (1950-2014 gg.) [The development of the universal musical education in China (1950-2014)] (Abstract of candidate's thesis, Belarusian State Pedagogical University named after Maxim Tank). Minsk, Republic of Belarus (in Russian).

Yan, Bohua. (2008). Muzykalnoe vospitanie v obshcheobrazovatel'noi shkole sovremennogo Kitaya [Music education in secondary school of modern China] (Candidate's thesis). St Petersburg, Russia (in Russian).

Ionova, E. \& Lakhmotova. Y. (2017). Question of learning English in the Waldorf schools of China. Virtus, 17, 109-111.

\section{Інформація про авторів:} Золотухіна Світлана Трофимівна

ORCID: http://orcid.org/0000-0002-35355974, доктор педагогічних наук, професор, завідувач кафедри загальної педагогіки i педагогіки вищої школи, Харківський національний педагогічний університет імені Г. С. Сковороди, Харків, вул. Валентинівська, 2, 61000 e-mail: kaf_pedagogik@ukr.net

\section{Іонова Олена Миколаївна}

ORCID:http://orcid.org/0000-0002-93065553, доктор педагогічних наук, професор, завідувач кафедри теорії i методики викладання природничоматематичних дисциплін у дошкільній, початковій і спеціальній освіті, Харківський національний педагогічний університет імені Г. С. Сковороди, Харків, вул. Валентинівська, 2, 61000 e-mail: elenaionova25@ukr.net

\section{Лупаренко Світлана Свгенівна}

ORCID:http://orcid.org/0000-0002-31115340, доктор педагогічних наук, професор, професор кафедри загальної педагогіки i педагогіки вищої школи, Харківський національний педагогічний університет імені Г. С. Сковороди, Харків, вул. Валентинівська, 2, 61000 e-mail: svetlana.luparenko@gmail.com

\section{Information about the authors: Zolotukhina Svitlana}

ORCID: http://orcid.org/0000-0002-35355974, Doctor of Pedagogical Sciences, Professor, Head of the Department of General Pedagogy and Pedagogy of Higher School, H. S. Skovoroda Kharkiv National Pedagogical University, Kharkiv, Street Valentynivska, 2, 61000

e-mail: kaf_pedagogik@ukr.net

\section{Ionova Olena}

ORCID:http://orcid.org/0000-0002-9306-

5553, Doctor of Pedagogical Sciences, Professor, Head of the Department of Theory and Methodics of Teaching NaturalMathematical Disciplines in Preschool, Primary and Special Education, H. S. Skovoroda Kharkiv National Pedagogical University, Kharkiv, Street Valentynivska, 2, 61000

e-mail: elenaionova25@ukr.net

\section{Luparenko Svitlana}

ORCID: http://orcid.org/0000-0002-31115340, Doctor of Pedagogical Sciences, Professor, Professor of the Department of General Pedagogy and Pedagogy of Higher School, H. S. Skovoroda Kharkiv National Pedagogical University, Kharkiv, Street Valentynivska, 2, 61000 e-mail: svetlana.luparenko@gmail.com

Цитуйте цю статтю як: Золотухіна С.Т., Іонова О.М., Лупаренко С.С. Музична освіта школярів у закладах загальної середньої освіти КНР: тенденції та перспективи. Теорія та методика навчання та виховання. 2019. № 47. С. 37-49

DOI: $10.34142 / 23128046.2019 .47 .04$

Дата надходження статті до редакції: 09.10.2019

Стаття прийнята до друку: 23.10.2019 